\title{
PENERAPAN MODEL PEMBELAJARAN INKUIRI TERBIMBING TERHADAP KEMAMPUAN PEMAHAMAN KONSEP MATEMATIS SISWA KELAS VIII MTS AL ISLAM PETALABUMI
}

\author{
Ramadhani Fitri ${ }^{1}$, Siska Aprilianingsih ${ }^{2}$ \\ ${ }^{1,2}$ Program Studi Pendidikan Matematika STKIP Insan Madani Airmolek \\ ramadhanifitri190418@gmail.com ${ }^{1}$
}

\begin{abstract}
Abstrak
Penelitian ini bertujuan untuk mengetahui pengaruh penerapan model pembelajaran inkuiri terbimbing terhadap kemampuan pemahaman konsep matematis siswa kelas VIII MTs Al Islam Petalabumi.Adapun jenis penelitian ini adalah penelitian Quasi Eksperimen. Rancangan penelitian yang digunakan adalah Randomized Subjects Posttest Only Control Group Design. Teknik pengambilan sampel adalah teknik purposive sampling.Instrument dalam penelitian ini berupa tes kemampuan pemahaman konsep matematis siswa. Teknik analisis data dalam pengujian ini menggunakan uji Independent Samples T-Test (Uji t). Berdasarkan hasil penelitian pengujian hipotesis terhadap kedua kelas sampel di peroleh nilai P-value lebih kecil dari $a$, yaitu $0,000<0,05$. Artinya bahwa $\mathrm{H}_{0}$ ditolak dan $\mathrm{H}_{\mathrm{a}}$ diterima. Dengan demikian kemampuan pemahaman konsep matematis siswa dengan penerapan model pembelajaran lebih baik dari pada kemampuan pemahaman konsep matematis siswa terhadap model pembelajaran konvensional.

Kata Kunci :pemahaman Konsep, inkuiri terbimbing
\end{abstract}

Abstract
This study aims to determine the effect of the Implementation of Guided Inquiry Learning Model Against the Mathematical Understanding Ability of Class VIII Students of MTs Al Islam Petalabumi. The type of this research is Quasi Experiment research. The research design used was Randomized Subjects Posttest Only Control Group Design. The sampling technique is a purposive sampling technique. The instrument in this study was a test of students' mathematical concept comprehension ability. Data analysis techniques in this test use the Independent Samples T-Test. Based on the results of research testing the hypothesis of the two sample classes obtained P-value is smaller than a, which is 0,000 <0.05. This means that HO is rejected and Ha is accepted. Thus the ability to understand students 'mathematical concepts with the application of guided inquiry learning models is better than the ability to understand students' mathematical concepts with conventional learning models.

Keywords: Concept Understanding, Guided Inquiry

\section{PENDAHULUAN}

Matematika sebagai salah satu mata pelajaran yang digemari oleh sebagian siswa juga memiliki tujuan tertentu dalam pembelajaran matematika. Menurut Wardhani (2008) pembelajaran matematika di sekolah memiliki tujuan agar siswa mampu :1).Memahami konsep matematika, menjelaskan keterkaitan antar konsep dan mengaplikasikan konsep secara luwes, akurat,efisien, dan tepat dalam pemecahan masalah. 2). Menggunakan penalaran pada pola dan sifat, melakukan manipulasi matematika dalam membuat generalisasi, menyusun bukti, atau menjelaskan gagasan dan pernyataan matematika. 3). Memecahkan masalah yang meliputi kemampuan memahami masalah, merancang model matematika, menyelesaikan model, dan menafsirkan solusi yang diperoleh. 4). Mengomunikasikan gagasan dengan simbol, tabel, diagram, atau media lain untuk memperjelas keadaan atau masalah. 5). Memiliki sikap menghargai kegunaan matematika dalam kehidupan, yaitu memiliki rasa ingin tahu, perhatian, dan minat dalam mempelajari matematika, serta sikap ulet dan percaya diri dalam pemecahan masalah.
Pemahaman matematis merupakan suatu kompetensi dasar dalam belajar matematika yang meliputi : kemampuan menyerap suatu materi, mengingat rumus dan konsep matematika serta menerapkannya dalam kasus sederhana atau dalam kasus serupa, memperkirakan kebenaran suatu pernyataan, dan menerapkan rumus dan teorema dalam menyelesaikan masalah.Pemahaman konsep dalam pembelajaran matematika sangat penting, karena dengan penguasaan konsep akan memudahkan siswa dalam mempelajari matematika. Pada setiap pembelajaran diusahakan lebih di tekankan pada penguasaan konsep agar siswa memiliki bekal dasar yang baik untuk mencapai kemampuan dasar yang lain seperti penalaran, komunikasi, koneksi dan pemecahan masalah.

Berdasarkan hasil observasi di Madrasah Tsanawiyah Al Islam (selanjutnya ditulis MTs Al Islam) pada tanggal 22-25 Oktober 2018, ditemui bahwa kemampuan pemahaman konsep siswa masih belum optimal, hal ini terlihat pada hasil rata-rata tes awal yang dilakukan peneliti pada tahap observasi, masih menunjukkan nilai dibawah Kriteria Ketuntasan Minimum (KKM)yang ditetapkan oleh MTs Al Islam Petalabumi 
yaitu 65. Jumlah siswa yang memperoleh nilai di atas KKM hanya 36,48 \% dari 74 siswa.

Solusi untuk mengantisipasi masalah tersebut agar tidak berkelanjutan adalah dengan cara menggunakan model pembelajaran yang tepat sehingga dapat meningkatkan pemahaman konsep matematis siswa agar mencapai hasil belajar yang baik. Salah satu model pembelajaran yang dipandang dapat meningkatkan pemahaman konsep matematis siswa adalah dengan model Inkuiri Terbimbing. Model pembelajaran Inkuiri Terbimbingadalah rangkaian kegiatan pembelajaran yang menekankan pada proses berfikir secara kritis, analitis untuk dapat mencari dan menemukan sendiri jawaban dari suatu masalah yang dipertanyakan.

Model pembelajaran Inkuiri Terbimbingini siswa belajar lebih berorientasi pada bimbingan dan petunjuk dari guru sehingga siswa lebih berperan aktif dalam pembelajaran dan siswa dapat memahami konsep-konsep pelajaran.Pada pendekatan ini siswa dihadapkan pada tugas-tugas yang relevan untuk diselesaikan baik melalui diskusi kelompok maupun secara individual agar mampu menyelesaikan masalah dan menarik suatu kesimpulan secara mandiri. Dalam model ini siswa dituntut untuk mencari dan berusaha menemukan sendiri jawaban dari permasalahan-permasalahan dalam proses belajar. Secara tidak langsung model ini menuntut siswa berperan aktif dalam proses pembelajaran sehingga guru tidak lagi menjadi pusat pembelajaran.Tujuan utama model Inkuiri Terbimbing adalah mengembangkan keterampilan intelektual, berfikir kritis, dan mampu memecahkan masalah secara ilmiah. Hal ini sejalan dengan pendapat Isrok'atun (2018) yang menyatakan bahwa dalam pelaksanaan pembelajaran inkuiri terbimbing memungkinkan siswa melakukan kegiatan penemuan dalam penyelesaian permasalahan yang diberikan oleh guru. Hal ini sudah dibuktikan pada penelitian Buyung (2017) bahwa pembelajaran dengan menggunakan Strategi pembelajaran inkuiri pada materi persamaan garis lurus bagi siswa kelas VIII SMP Negeri 18 Singkawang Selatan terdapat peningkatan kemampuan pemahaman konsep, aktivitas baik dan respon siswa terhadap SPI adalah positif (senang).

\section{METODE}

Penelitian ini merupakan penelitian Quasi Exsperimental Design.Dengan bentuk Randomized Posstest Only Control Group Design.Dapat digambarkan pada Tabel 1 berikut.

Tabel 1. Desain Penelitian

\begin{tabular}{|c|c|c|c|}
\hline & Group & Variabel Terikat & Posttest \\
\hline $\mathrm{R}$ & Kelas Eksperimen & $\mathrm{X}$ & $\mathrm{Y}_{2}$ \\
\hline $\mathrm{R}$ & Kelas Kontrol & - & $\mathrm{Y}_{2}$ \\
\hline
\end{tabular}

(Sumber : Darmadi,2013)

$$
\begin{aligned}
& \mathrm{R}=\text { Randomisasi } \\
& \mathrm{X}=\text { Perlakuan } \\
& \mathrm{Y}_{2}=\text { Posstest }
\end{aligned}
$$

Dalam hal ini pengambilan sampel dilakukan dengan teknik purposive sampling, Berdasarkan pertimbangan peneliti dan guru mata pelajaran matematika kelas VIII maka di ambil kelas VIII $^{\mathrm{A}}$ dan $\mathrm{VIII}^{\mathrm{B}}$, karena kedua kelas tersebut memiliki kemampuan akademik yang tergolong sama. Setelah diperoleh dua kelas sampel maka ditentukan kelas VIII $^{\mathrm{A}}$ sebagai kelas eksperimen dan kelas VIII ${ }^{\mathrm{B}}$ sebagai kelas kontrol.

.Teknik pengumpulan data berupa tes, instrumen penelitian ini yaitu tes kemampuan pemahaman konsep matematis siswa, jenisnya berupa uraian.Teknik analisis data pada penelitian ini untuk menguji hipotesis secara statisticdengan ujiIndependent Samples T-Test atau uji t. sebelum melakukan uji t terlebih dahulu melakukan uji normalitas dan uji homogenitas dari kedua kelas sampel.Analisis ini dilakukan terhadap data hasil posttest yaitu tes kemampuan pemahaman konsep matematis siswa.

\section{HASIL PENELITIAN DAN PEMBAHASAN}

Data kemampuan pemahaman konsep matematis siswa diperoleh dari hasil perhitungan secara statistik dapat dilihat padaTabel 2 berikut.

Tabel 2. Hasil Perhitungan Data Tes Pemahaman Konsep

\begin{tabular}{|l|c|c|c|c|c|}
\hline \multicolumn{1}{|c|}{ Kelas } & $\mathrm{N}$ & $\mathrm{X}_{\min }$ & $\mathrm{X}_{\text {maks }}$ & $X$ & $\mathrm{~S}^{2}$ \\
\hline Eksperimen & 27 & 80 & 92 & 85,67 & 13,08 \\
\hline Kontrol & 26 & 67 & 89 & 77,08 & 29,43 \\
\hline
\end{tabular}

Dari Tabel 2 diatas, terlihat bahwa nilai rata-rata kemampuan pemahaman konsep matematika siswa kelas eksperimen 85,67 dan kelas kontrol adalah 77,08. Standar 
deviasi kelas eksperimen lebih kecil daripada kelas kontrol, yaitu 13,08 kelas eksperimen dan 29,43 kelas kontrol.

Untuk menarik kesimpulan dari hasil penelitian yang dilakukan, maka data yang diperoleh dari tes kemampuan pemahaman konsep matematis siswa dilakukan analisis secara statistik yaitu dengan Independent Samples T-Test atau uji t. Sebelum melakukan uji $\mathrm{t}$ terlebih dahulu penulis melakukanuji normalitas dan uji homogenitas.

Tabel 3. Hasil Perhitungan Uji Normalitas Kedua Kelas Sampel

\begin{tabular}{|c|c|c|c|}
\hline Sampel & Nilai Sig & Nilai $\alpha$ & Keputusan \\
\hline Eksperimen & 0,081 & 0,05 & Normal \\
\hline Kontrol & 0,459 & 0,05 & Normal \\
\hline
\end{tabular}

Dari Tabel 3 terlihat bahwa nilai signifikan pada kelas eksperimen adalah 0,081 dan nilai signifikan pada kelas kontrol adalah 0,459 . Karena signifikan pada kedua kelas sampel lebih besar dari $\alpha=0,05$ maka dapat disimpulkan $\mathrm{H}_{0}$ diterima, artinya nilai posttest kelas sampel berdistribusi normal.

\section{Uji Homogenitas}

Uji homogenitas menggunakan rumus $U j i$ $F$.Berdasarkan hasil pengujian diperoleh output yang menunjukkan bahwa signifikansi sebesar $0,332>0,05$ hal ini berarti $\mathrm{H}_{0}$ diterima, artinya variansi nilai posttest siswa kelas eksperimen dan kelas kontrol keduanya homogen.

\section{Uji Hipotesis}

Setelah sampel berdistribusi normal dan memiliki variansi homogen maka dilanjutkan dengan uji hipotesis dengan cara menggunakan uji-t.berdasarkan hasil pengujian pada tebel Independent Sample TTest menunjukkan bahwa nilai signifikan lebih kecil dari $\alpha$, yaitu $0.000<0,05$. Hal ini berarti sebagaimana dasar pengambilan keputusan dalam uji independent sample test dapat disimpulkan bahwa $\mathrm{H}_{0}$ ditolak dan $\mathrm{H}_{\mathrm{a}}$ diterima.Artinya terdapat perbedaan kemampuan pemahaman konsep matematis antara kelas eksperimen dan kelas kontrol. Hal ini dapat dilihat darirata-rata kemampuan pemahaman konsep matematika siswa kelas eksperimen yang diperoleh yaitu 85,67 sedangkan kelas kontrol yaitu 77,08.Dengan demikian dapat disimpulkan bahwa kemampuan pemahaman konsep matematis siswa dengan penerapan model pembelajaran Inkuiri Terbimbinglebih baik dari pada kemampuan pemahaman konsep matematis siswa terhadap pembelajaran konvensional pada kelas VIII MTs Al Islam Petalabumi.

Berdasarkan hasil penelitian yang telah dilakukan menunjukkan bahwa pemahaman konsep matematis siswa yang diajar dengan model pembelajaran inkuiri terbimbing lebih baik dari pada siswa yang diajar dengan model konvensional. Hal ini dikarenakan pada tahap model pembelajaran inkuiri terbimbing dapat melatih siswa dalam menemukan jawaban sendiri dari suatu masalah yang diberikan sehingga membentuk siswa untuk berfikir kritis. Hal inisejalan dengan pendapat Iswadi (2017) menyatakan bahwa metode ini menuntut siswa memperoleh pengalaman belajar yang bermakna sehingga siswa terbiasa untuk produktif, analitis dan kritis. Berikut dideskripsikan kemampuan pemahaman konsep matematis siswa dari masing-masing indikator yang diukur.

1. Kemampuan menyatakan ulang sebuahkonsep

Kemampuan siswa dalam menyatakan ulang sebuah konsep matematika yang sesuai pada objek menurut sifat-sifat tertentu dapat dilihat berdasarkan jawaban siswa pada soal no.1 kelas eksperimen dan kelas kontrol pada hasil tes kemampuan pemahaman konsep matematis siswa. Hasil tes siswa dapat di lihat pada gambar 1.

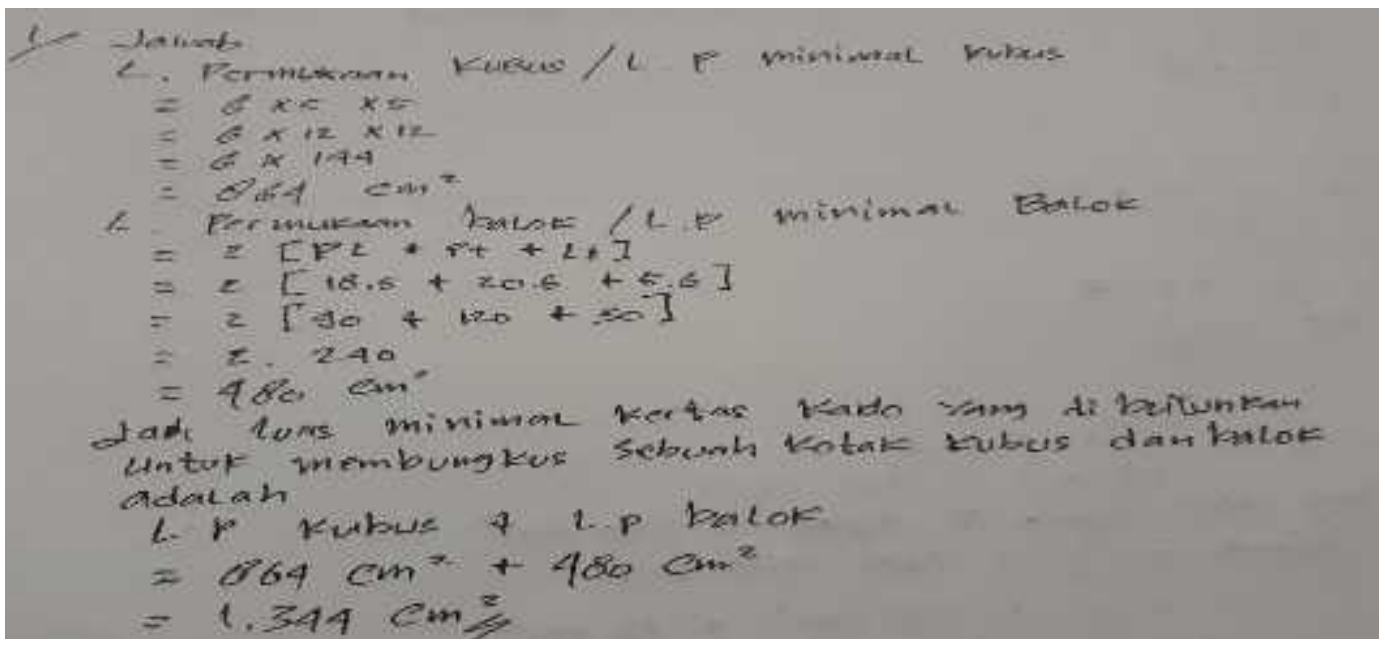

Gambar 1. Hasil jawaban siswa pada kelas eksperimen 
Dari hasil jawaban yang dikerjakan oleh siswa kelas eksperimen, terlihat siswa dapat menyatakan ulang sebuah konsep matematika sesuai pada gambar yang terdapat pada soal no. 1 dengan baik, dimana terdapat sebuah gambar gabungan kotak yang berbentuk kubus dan balok. Dalam menjawab soal no.1 terlihat pemahaman konsep siswa sangat baik, oleh karena siswa pada kelas eksperimen ini dapat menerapkan konsep dalam perhitungan matematis dengan tepat dan benar. Jawaban yang diberikan pada kelas eksperimen juga terlihat sangat terstruktur dan jelas. Sedangkan di kelas kontrol dapat dilihat pada gambar 2 sebagaiberikut.

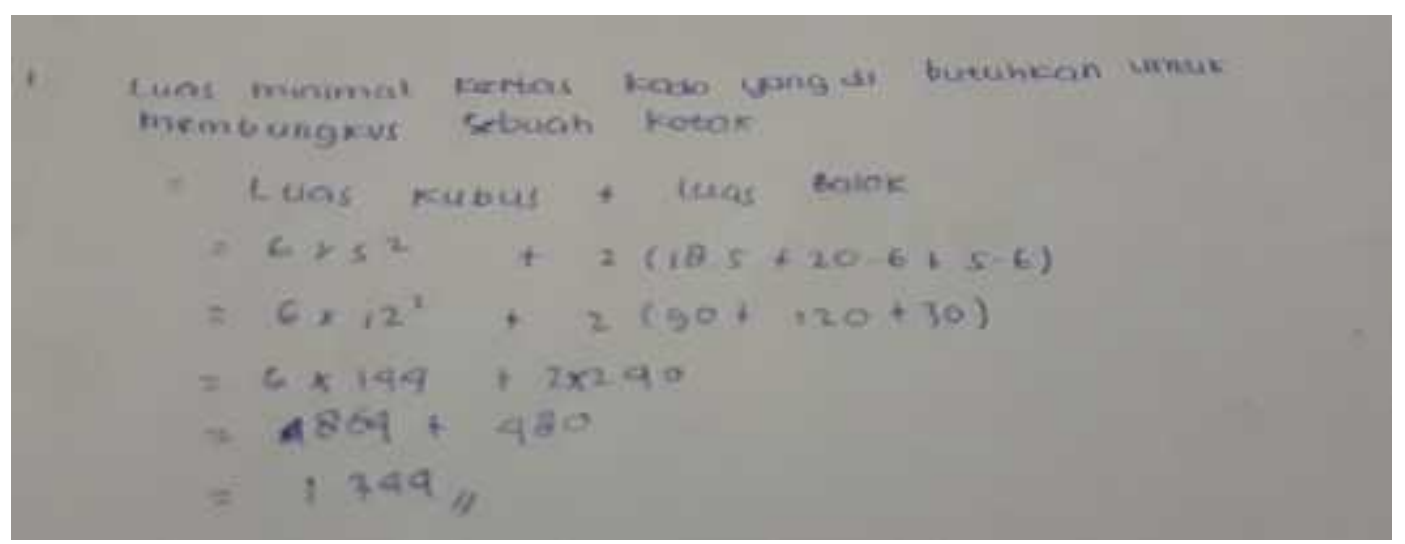

Gambar 2. Hasil jawaban siswa pada kelas kontrol

Dari hasil jawaban siswa kelas kontrol diatas, terlihat siswa dapat menjawab soal dengan benar, namun cara penyelesaiannya tidak tersetruktur dengan baik dan masih bersifat coba-coba. Hal ini dikarenakan pemahaman siswa dalam menyatakan ulang sebuah konsep matematika pada soal no.1 kurang baik. Dari deskripsi soal no.1 kelas eksperimen dan kontrol, terlihat bahwa kemampuan menyatakan ulang sebuah konsep matematika kelas eksperimen lebih baik dari kelaskontrol.
2. Kemampuan Menyajikan konsep dalam berbagai bentuk representasimatematis

Kemampuan_menyajikan konsep dalam berbagai bentuk representasi matematis siswa pada kelas sampel ditinjau dari hasil tes pemahaman konsep siswa. Pada soal indikator ini terdapat pada soal nomor 2 . Dimana siswa kelas eksperimen dan kelas kontrol diminta untuk menentukan volume dari sebuah bak mandi dengan ukuran $2 \mathrm{mx}$ $1 \mathrm{~m} \times 1,5 \mathrm{~m}$ dan bak tersebut sudah terisi air $1 / 2$ bagian. Jawaban padakelas eksperimen dapat dilihat pada gambar 3 berikut.

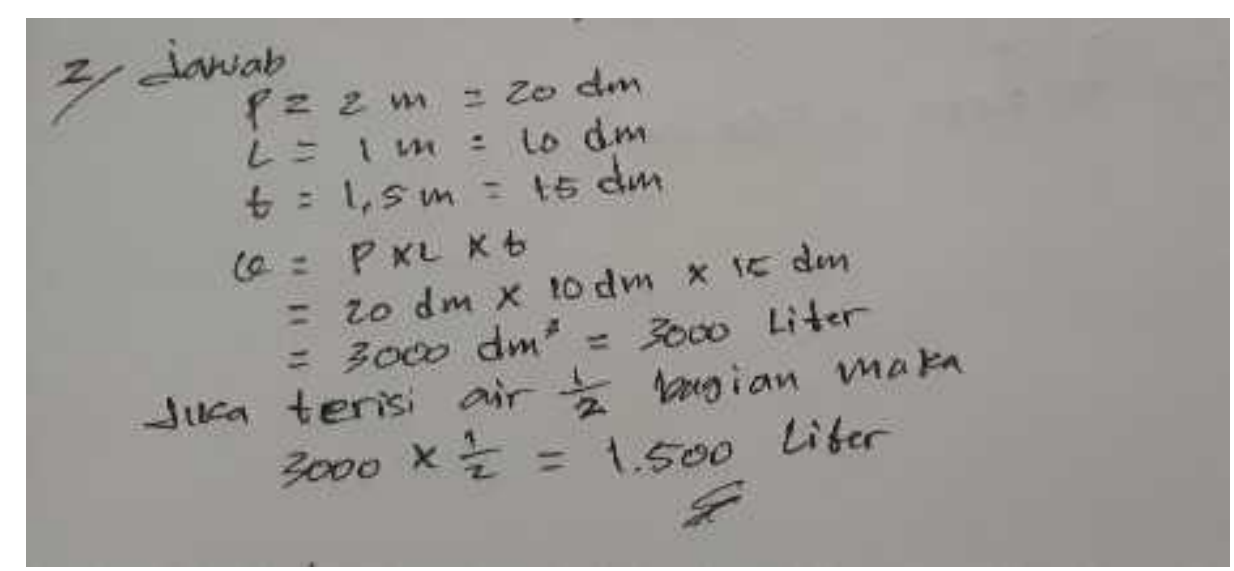

Gambar 3. Hasil jawaban siswa pada kelas eksperimen

Dari jawaban kelas eksperimen diatas, dapat dilihat siswa mampu memaparkan konsep matematika secara berurutan dan siswa dapat menyajikan suatu konsep matematika dengan baik dan benar, dan jawaban yang didapat lebih terarah dan sistematis. Sedangkan jawaban pada kelas kontrol dapat dilihat pada gambar 4 berikut. 


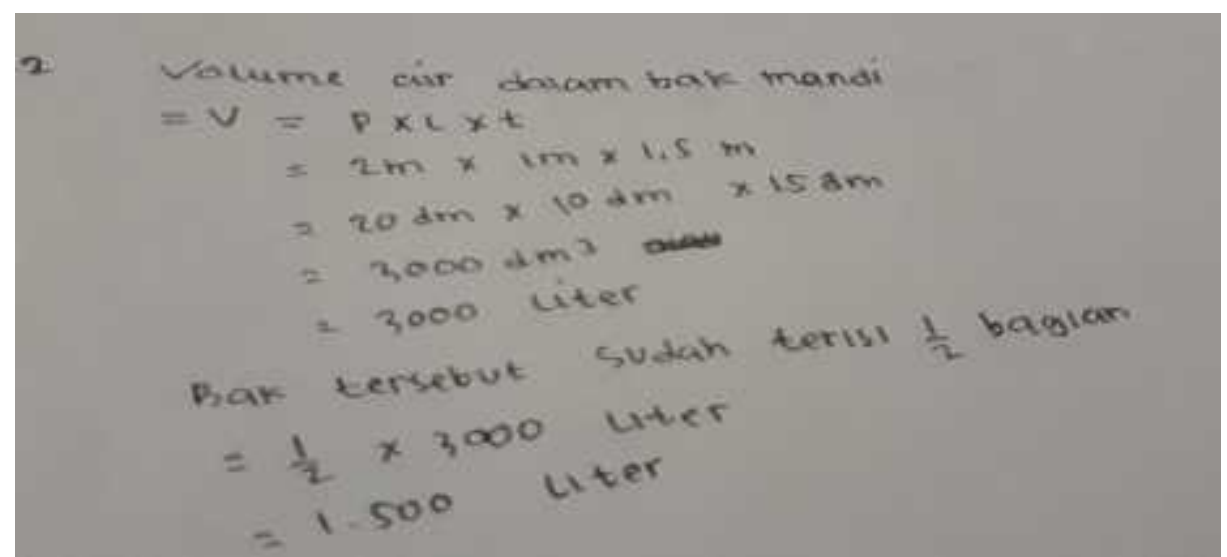

Gambar 4. Hasil jawaban siswa pada kelas kontrol

Dari jawaban siswa kelas kontrol diatas, jawaban siswa benar, tetapi jawaban siswa kurang sistematis dan kurang terarah, hal ini menunjukkan siswa dalam kelas kontrol belum sepenuhnya mampu menyajikan sebuah konsep dalam bentuk representasi matematika dengan baik.Dari deskripsi jawaban siswa kelas kontrol dan kelas eksperimen dapat dilihat bahwa kemampuan menyajikan konsep matematika dalam berbagai bentuk representasi matematika pada kelas eksperimen lebih baik daripada kelas kontrol. Hal ini dikarenakan pada kelas eksperimen diterapkan model pembelajaran Inkuiri Terbimbing, dimana pada kegiatan pembelajaran siswa lebih dilatih untuk berfikir kritis dalam menemukan suatu jawaban dari permasalahanmatematika. Hal ini juga ditunjukkan pada hasil penelitian Purwanti
(2017) bahwa ada pengaruh metode pembelajaran inkuiri terhadap pemahaman konsep matematika pada materi bangun datar dan satuan pengukuran.

3. Mengembangkan syarat perlu atau syarat cukup suatukonsep

Kemampuan mengembangkan syarat perlu atau syarat cukup suatu konsep matematika pada kelas sampel ditinjau dari hasil tes pemahaman konsep siswa pada soal indikator ini terdapat pada soal nomor 3 . Dimana siswa kelas eksperimen dan kelas kontrol diminta untuk menentukan luas minimum kertas karton yang akan diperlukan untuk membuat 5 buah papan nama yang bagian kanan dan kirinya terbuka (prisma tanpa alas) Dimana jawaban pada kelas eksperimen dapat dilihat pada gambar 5 berikut.

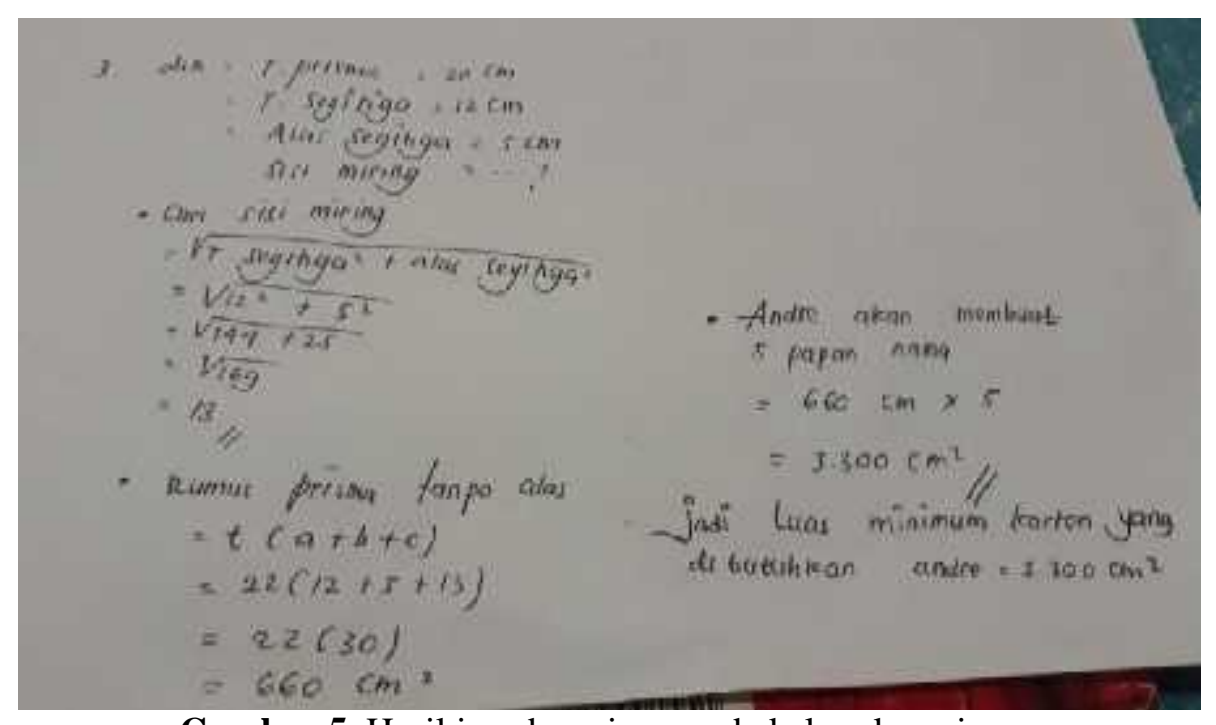

Gambar 5. Hasil jawaban siswa pada kelas eksperimen

Dilihat pada gambar jawaban kelas eksperimen siswa mampu menganalisa suatu soal mana syarat yang perlu atau cukup pada soal nomor 3. siswa dapat memahami suatu materi dengan melihat syarat- syarat yang diperlukan, karena berdasarkan soal nomor 3 siswa diminta untuk menentukan rumus yang harus digunakan jika sebuah karton untuk membuat papan nama tersebut bagian kanan dan kirinya terbuka (prisma tanpa alas), sehingga yang tidak diperlukan harus dihilangkan. Dilihat pada jawaban kelas eksperimen, jawaban siswa sangat terarah, sistematis dan baik dan dapat dilihat pemahaman konsep pada kelas eksperimen terhadap soal yang diberikan sangat baik. Sedangkan pada kelas kontrol dapat dilihat pada gambar 6 berikut. 


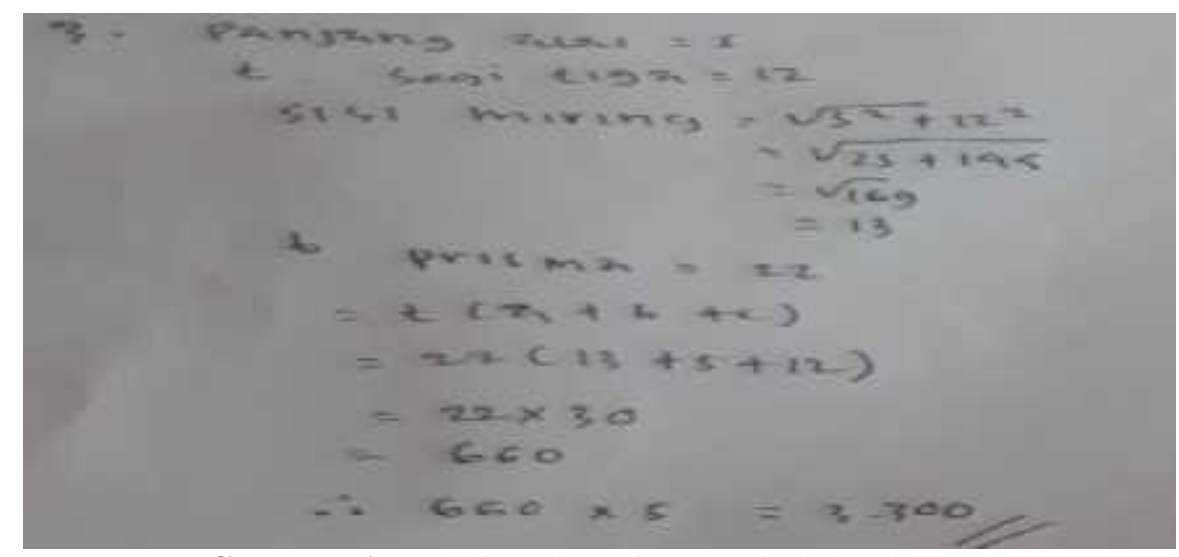

Gambar 6. Hasil jawaban siswa pada kelas kontrol

Dari jawaban siswa kelas kontrol dapat dilihat bahwa jawaban siswa benar, tetapi dalam menjawab sebuah persoalan matematika yang terdapat pada soal nomor 3 jawaban siswa kelas kontrol tersebut kurang terarah, sehingga dapat disimpulkan dalam mengembangkansyarat perlu atau syarat cukup suatu konsep matematika, kelas eksperimen lebih baik dari kelas kontrol.

\section{SIMPULAN}

Berdasarkan hasil penelitian pengujian hipotesis terhadap kedua kelas sampel di peroleh nilai $P$-value lebih kecil dari $a$, yaitu $0,000<0,05$. Artinya bahwa $\mathrm{H}_{0}$ ditolak dan $\mathrm{H}_{\mathrm{a}}$ diterima. Dengan demikian terdapat perbedaan yang signifikan antara rata-rata hasil belajar siswa yang mana kelas eksperimen dengan menggunakan model pembelajaran inkuiri terbimbing lebih baik dibandingkan kelas kontrol yang menggunakan model pembelajaran konvensional. Sehingga dapat disimpulkan bahwa "kemampuan pemahaman konsep matematis siswa dengan penerapan model pembelajaran Inkuiri Terbimbinglebih baik dari pada kemampuan pemahaman konsep matematis siswa terhadap pembelajaran konvensional pada kelas VIII Madrasah Tsanawiyah Al Islam Petalabumi”.

\section{REFERENSI}

Buyung, B., \& Khasan, N. (2017). Strategi Pembelajaran Inkuiri (SPI) Terhadap Kemampuan Pemahaman Konsep. PRISMA, Prosiding Seminar Nasional Matematika, 223-229. Retrieved from

https://journal.unnes.ac.id/sju/index.php/pr isma/article/view/21617

Darmadi, H. (2013). Metode Penelitian dan Sosial. Bandung: Alfabeta

Isrok'atun. (2018). Model-model Pembelajaran Matematika. Jakarka: Bumi Aksara

Iswadi. (2017). Teori Belajar. Bogor: PT In Media

Purwanti, K. L. (2017). Efektifitas Metode Inkuiri Untuk Meningkatkan Kemampuan Literasi Dan Pemahaman Konsep Matematika Mahasiswa Calon Guru MI. PRISMA, Prosiding Seminar Nasional Matematika, 466-480. Retrieved from https://journal.unnes.ac.id/sju/index.php/pr isma/article/view/21553

Wardhani, S.,dkk. (2008). Analisis SI dan SKL Mata Pelajaran Matematika SMP/MTs untuk Optimalisasi Tujuan Mata Pelajaran Matematika. Yogyakarta: Pusat Pengembangan Dan Pemberdayaan Pendidik Dan Tenaga Kependidikan Matematika 